\title{
TRANSITION OF ENTREPRENEURIAL UNIVERSITY: FROM LOCAL TO INTERNATIONAL
}

\author{
Eglè Girdzijauskaitè ${ }^{1}$, Asta Radzevičienè ${ }^{2}$, Artūras Jakubavičius ${ }^{3}$ \\ Vilnius Gediminas Technical University, Sauletekio al. 11, LT-10223 Vilnius, Lithuania \\ E-mails: ${ }^{1}$ egle.girdzijauskaite@vgtu.lt (corresponding author); \\ 2asta.radzeviciene@vgtu.lt; ${ }^{3}$ a.jakubavicius@lic.lt
}

\begin{abstract}
Universities are becoming entrepreneurial due to highly competitive environment, decreased government funding and external and internal pressure to generate income from research and education services. It is argued in literature that the competitiveness of higher education institutions (HEIs) will increasingly depend on their ability to operate internationally in the near future. However, the knowledge of entrepreneurial university management especially the ways to create the international presence and provide educational services cross-border is lacking and this research is contribution to filling this gap. The transition of higher education conception from public good to private good or tradable service in line with the contemporary theories and practices in international higher education have been analysed in the paper to illustrate the shift in approach to international activities of HEIs. The paper undertakes an analysis of the premises associated with the entrepreneurial model of university management, as well as analysis illustrating the growing transnational education (TNE) consumption globally and the growth of international education market as the potential venue of an entrepreneurial university.
\end{abstract}

Keywords: entrepreneurial university, export of educational services, internationalisation of higher education, strategic management of universities, international education, business models in higher education.

JEL Classification: I23; I25.

\section{Introduction}

Higher education (HE) is experiencing a vast transition around the world: the changing relationship between the universities and the governments, increased demand for HE, new kind of competitors emerging - private R\&D organisations and businesses. Such conditions resulted in increasing numbers of providers of international education, increasing competition and shift in universities' management, strategies and operations.

Growing competition and scope of competitors, as well as the need to be more self-reliant determines that the competitiveness of higher education institutions (HEIs) will increasingly depend on their ability to apply entrepreneurial principles to their local and international activities in the near future.

However, the current knowledge of entrepreneurial management, especially the ways to create international presence and provide educational services cross-border, is moderately applied in many universities.

\section{Higher education: from public to tradable service}

Since the establishment of the first universities in 13th century in Europe until the 20th century, the mission of educating the society and developing fundamental knowledge were declared (often stressing the principles of Humboldtian university); the state assumed the function of financing higher education. However, since the eighties of 20th century the need to tune university activities with the practical needs of society development emerged. This requires the ability to provide services in the market conditions, basically, to be able to compete for the customer and generate revenue for their services (through tuition fees, contracted work, etc.). This illustrates an apparent shift of higher education from public good to tradable service during the last two decades (Knight 2006; Tilak 2008).

The concept of public good is central to economic analysis of government role in the resource allocation. Public goods are defined by two characteristics:

- Non-excludability: it is impossible to exclude non-payers from consuming the good.

- Non-rivalry in consumption: additional people consuming the good do not diminish the benefit to others. 
Considering the latter definition it is evident that in most countries higher education is not entirely a public good anymore. People who are not able or willing to pay (e.g. tuition fees) for educational services may be excluded: the share of paid educational services is growing globally.

This shift is proceeding in the context of decreasing state allocations for higher education. The new public funding models are based on objective measurable indicators of university performance results - this way the state retains the influence on universities. Under such circumstances universities are forced increasingly to generate income while competing under the market conditions. Naturally, organisational behaviour similar to that of business companies is becoming increasingly common for all kinds of educational institutions (Pinheiro, Stensaker 2014).

\section{The rise of entrepreneurial university}

Universities are responding globally on the changing environment by applying innovative approach throughout its research, knowledge exchange, teaching and learning, governance and external relations (OECD 2012). The quickly growing trend of prospective business models applied in higher education management is marking the emergence of entrepreneurial university phenomena (Clark 1998, 2001; Gallagher, Garrett 2012).

There is a vast variety of literature addressing the entrepreneurial university as a phenomenon (Wasser 1990; Clark 1998; Currie 2002; Barsony 2003; Jacob et al. 2003; Lazzeroni, Piccaluga 2003; Etzkowitz 2004; Gibb, Hannon 2006; Kirby 2006; Wong et al. 2007; Guerrero-Cano 2008; Mohrman et al. 2008).

It is stressed in the literature that one of the main features of an entrepreneurial university is looking forward and pursuing the opportunities beyond available means (Clark 1998) and being a self-reliant organisation. In other words, it does not rely completely on the public sources, privately gained income takes a significant share on a balance sheet. Entrepreneurial university takes risks in order to cover the financial shortages and reinvest the gain in new ventures.

The entrepreneurial university is self-steering. In line with diminishing external regulation of university activities, the financial, legal and academic autonomy of universities is increasing, although the responsibility and accountability to society is being increased through business and research partnerships, funding schemes, etc.
It is suggested in the literature that one important feature of an entrepreneurial university is that it is capable of responding flexibly, strategically and yet coherently to the emerging opportunities. According to Clark (1998) this is "strong steering core with acceptance of a model of selfmade autonomy" across the academic departments. It is clear that the more autonomous university the more flexible and responsive it is able to be. The so called "entrepreneurial response" has become an imperative to the universities that want to be a powerful player in the competitive and dynamic HE playground.

\section{Shifting mission}

Traditionally, the mission of a university used to be two-fold: 1) executing research and studies; 2) producing and disseminating the knowledge. In modern times "the third mission" has been increasingly recognized in the agendas of universities (Etzkowitz 2006; Gulbrandsen, Slipersaeter 2007; Fayolle, Redford 2014).

Approximately 15 years ago when the emergence of an "entrepreneurial university" was elaborated in the works of Etzkowitz (2004) and Clark (1998), a "third mission" of contributing to economic development had emerged alongside the "first mission" of teaching and the "second mission" of conducting basic research (Trencher et al. 2014). The third mission has been defined in literature as identifying, creating and commercialising intellectual property (Etzkowitz et al. 2000) and contributing to regional or national economic performance as well as the university's financial vantage and that of its faculty (Etzkowitz et al. 2000; Trencher et al. 2014).

The latter epitomisation of the third mission of the universities concerns the collaboration between university and external stakeholders (Sam, van der Sijde 2014) and a so called Triple Helix of University-Industry-Government relations (Etzkowitz 2006), followed by the Quadruple and Quintuple Helix models (Leydesdorff 2012). Higher education institutions are increasingly demanded for social responsibility, for wider involvement and contribution to the different stakeholders of the society. It is expected of universities to increasingly engage in various forms of cooperation with local, regional, national and international business and social partners (Ćulum et al. 2013).

The traditional missions of university are undergoing turbulent times. Governments demand for an increasing number of students, the curricula must reflect the employment market needs, the ex- 
cellence of teaching and research must be achieved in a way that is measurable, efficient, and relevant for the contemporary knowledge-economy and society at large (Göransson et al. 2009; Culum et al. 2013). Contrary to the latter challenges, universities have been criticized for the loss of academic identity and being too much market driven. This raises the main challenge: seek entrepreneurial model, preserve academic values, and do not lose the balance in between.

\section{The pillars of entrepreneurial management culture}

In order to meet the needs of all stakeholders and develop an entrepreneurial culture in an institution, it is important to have a strong leadership and governance.

One of the main elements of entrepreneurial management model is overcoming the traditional bureaucratic barriers: universities with fewer hierarchies undertake entrepreneurial activities faster. It is widely recommended that universities promote the autonomy of units and individual ownership of initiatives, very often leading to full cost model and strict R\&D management at academic unit level. This way the creation and development of ideas or new organizational structures is enhanced. The mechanisms for breaking down traditional boundaries and fostering new relationships - bringing internal stakeholders together (staff and students) and building synergies between them must be developed. Internal stakeholders of the university should create synergies and linkages across faculties, departments and other structures, breaking down traditional boundaries, contributing to entrepreneurial agenda. An entrepreneurial university should have instruments to exploit the existing internal knowledge and resources.

Another important element of entrepreneurial university management model is an advanced human resource strategy. Entrepreneurial university invests in staff development as human resource is its most valuable resource and the one that considerably drives the entrepreneurial agenda of the university. Entrepreneurial agenda is associated with constant upskilling, therefore, the adaptive policy of professional training and staff career development is a very important element of entrepreneurial university human resource management strategy.

\section{Financial strategy}

Another important feature of the entrepreneurial university is the diversified funding base. High dependence on one funding stream delays the process of creating a self-reliant university (Clark 2015). Diversified funding enables to decide independently and therefore not only provides more freedom but also fastens the processes.

The streams of income can be classified in numerous ways. Clark (2001) categorizes it as follows: mainline institutional support from a governmental ministry; funds from governmental research councils; and all other sources lumped together as "third-stream income". According to Clark, such diversification of income is essential for entrepreneurial university (Clark 2015).

The third-stream funds category by Clark (2001) includes several types of income sources, such as:

- other governmental sources (other departments at the same level of government, such as departments of technology, economic development; departments of regional and city governments);

- private organized sources (industrial firms; philanthropic foundations offering specific funds and unearmarked funds);

- university-generated income (income from endowment and investments; income from campus services; student tuition fees; alumni fundraising; royalty income from patented intellectual property).

Certain pros and cons lie behind the latter funding sources diversification model. The main pros are greater independence from government funding and flexibility managing risks and downturns in the local market. However expenditure discretion is limited to some extent. Universityindustry collaborations involve bargaining and compromises over whose interest has priority, government departments may offer generous, relatively unearmarked grants, or they may insist on tight accounting. But "university-generated income" is the one with least limited expenditure discretion. Activities defined under the university-generated income, as well as private organized funds category, require certain organizational behavior typical of business companies seeking profit.

The decreasing state funding for universities has been offset by private-organized sources and university generated income. However the income generated from education and research services provided on competitive basis has the most impact as a stream of income (typically, the part generated by European HEIs makes about 25-35 percent of the total budget), requiring more and more proactive business-like approach. 
Having current numbers of international students at universities it becomes evident that international education is foremost a business and financial interests are at stake. In some countries (e.g. the Netherlands, Sweden, Denmark) substantial tuition fees have been introduced for non-EU students, which institutions use to increase and diversify income.

The latter insights enhances the notion that a university can be international without being entrepreneurial, but there is no way to be entrepreneurial without being international.

\section{From local to international}

The entrepreneurial university explores regional, national, and international markets. The means of international expansion are growing in diversity and scope. Since knowadays international activities are integral and unavoidable part of all universities, entrepreneurial universities find themselves being engaged in the most risky and advanced modes of internationalization.

The rationales for international expansion are various. We emphasize three categories in this paper: enhancement of knowledge, physical and financial resources.

Knowledge resources group is the most important one in any knowledge-intensive organization, especially university. Engagement into internationalisation acitivities is raising the qualification capacities of students and staff (outgoing and incoming mobility, international research and knowledge exchange). All this eventually creates a more rich service portfolio for internal and external stakeholders.

The second rationale - physical capital is about the infrastructure development of universities through various forms of cooperation (joint ventures, joint projects) or transfer of good practices and bringing ideas for new establishments or improvement of the old ones (Radzeviciene, Girdzijauskaite 2012).

The financial resources rationale emphasizes the income diversification through income from international activities, increase of revenue. Trade in HE is recognized as "business" already for a few decades (Burnett 2008; Knight 2002c, 2003). And together with the growing need for local higher education, the demand has been growing for transborder education such as international branch campuses, twinning arrangements with other universities, corporate universities, virtual universities, open universities and e-universities (Burnett 2008; Knight 2002a, 2002b; Wilkins, Huisman 2013).
Together with the recent technological revolution and the massive growth in online learning, this "business" is facing perfectly fertile market conditions (Burnett 2008).

\section{Export of education services}

Export of higher education services is one of the key capacities enhancing the performance of the entrepreneurial university.

Export of educational services is often referred to as transnational education in literature. One of the first definitions of TNE by Global Alliance for Transnational Education: "Transnational Education denotes any teaching or learning activity in which the students are in a different country (the host country) to that in which the institution providing the education is based (the home country). This situation requires that national boundaries be crossed by information about the education, and by staff and/or educational materials." (GATE 1997). British Council (undated) state: "Transnational education, in brief, means delivering education where the learners are located in a different country from the one where the awarding institution is based".

There are several transnational education modes: international branch campus, franchise or twinning programmes, articulation agreements, double/dual degree programmes, joint degree programmes, etc. British Council defines TNE activities as follow:

1. International branch campus. The sending HEI establishes a stand-alone satellite operation known as an international branch campus (IBC) in the host country and is responsible for all aspects of recruiting, admission, programme delivery and awarding of the qualification. The faculty can be both employed locally and internationally, and the latter proportion varies in different cases.

2. Franchise/twinning programmes. The sending HEI authorises a host HEI to deliver its programme, with no curricular input by the host institution. The qualification is awarded and quality assured by the sending HEI. The host HEI has primary responsibility for delivery of the programme but the sending HEI may assist with delivery of the programme by providing flying teaching faculty.

3. Articulation agreements. Allow host country students who have completed a specified curriculum (award not of the sending HEI) to apply to a sending country programme and enrol with "advanced standing".

4. Double/dual degree programmes. Two or more partner institutions in different countries de- 
sign and deliver a study programme collaboratively. Student and faculty mobility between partner HEIs varies. Students receive a qualification from each partner institution.

5. Joint degree programmes. The joint degree programme is similar to the double/dual degree programme in that two or more HEIs collaborate to design and deliver a new programme. The sole difference is that students receive one qualification which includes the badges of each partner institution on the award.

6. Validation programmes. The process by which a sending HEI judges that a programme developed and delivered by a host HEI is of an appropriate quality and standard to lead to a degree from the sending HEI. The host HEI can develop a programme to meet local needs with the sending HEI contributing its quality assurance processes.

7. Other. Access/feeder programmes, credit transfer/study abroad programmes, short-term or partial credit programmes, distance learning programmes/virtual universities, tuition providers/ teaching centres, binational campuses, independent campuses, corporate training and intermediary agencies.

The most entrepreneurial transnational education activity is international branch campus. Income generated from transnational activities enables the financial diversification of an institution and lower dependency on local government allocations.

It is stressed in knowadays HE research that HE sector is becoming a service market. Developing BRICS $^{1}$ and MINT $^{2}$ economies are ones of the mostly growing HE markets. Despite the changing customer segment, the main providers of international education remain rather unchanged: UK, USA, Australia.

The economic importance of international higher education is growing (Naidoo 2008). Higher education is among the top service sector export in Australia, United States and United Kingdom. In total English speaking countries own a global market share of over $65 \%$ and talk about the "industry" that generates a significant source of income when referring to the internationalisation of higher education.

Attracting foreign students is stressed in most countries national HE internationalisation strategies, however these initiatives differ in results. Talking about income generated from international students it does not exceed 1-2 percent of HEIs

\footnotetext{
${ }^{1}$ Brazil, Russia, India, China, South Africa.

2 Mexico, Indonesia, Nigeria, Turkey.
}

budgets in Lithuania while Australian and UK universities generate 60 percent.

Income related to incoming international students may vary up to 20 percent in majority of European universities. So long the most advanced countries in this field have been the USA, UK and Australia (major TNE providers): HEIs in the latter countries generate 60 percent of total income by attracting international students paying tuition fees. This enables universities to decrease the dependency from government funding and proves economic value of $\mathrm{HE}$ international activities.

For the transnational education development HEIs are increasingly turning to developing markets: Brazil, Russia, India, China, Central Asian countries. According to the report by the Boston Consulting Group 100 million people will enter the consumer class (with annual income of more than $\$ 5,000$ ) in 2016 in six south-east Asian countries (Indonesia, Malaysia, the Philippines, Singapore, Thailand and Vietnam). This segment is reffered to as glocals - a new share of students who are willing to pay for a global educational experience while staying in their home region.

It's also important that TNE flows between the countries also correlate with the business trade flows. However, business relations between countries are developed earlier than TNE flows, and not wise versa.

Australia. International education activity contributed AUS $\$ 18.1$ billion (US $\$ 13.14$ billion) in export income to the Australian economy in 2014-2015 (Fig. 1). Roughly \$600 million of it was generated from a range of international education services delivered by Australian providers offshore. This represents a $14.2 \%$ increase on the AUS $\$ 15.9$ billion recorded for the previous year, and secures the sector's position as Australia's fourth-largest export industry.

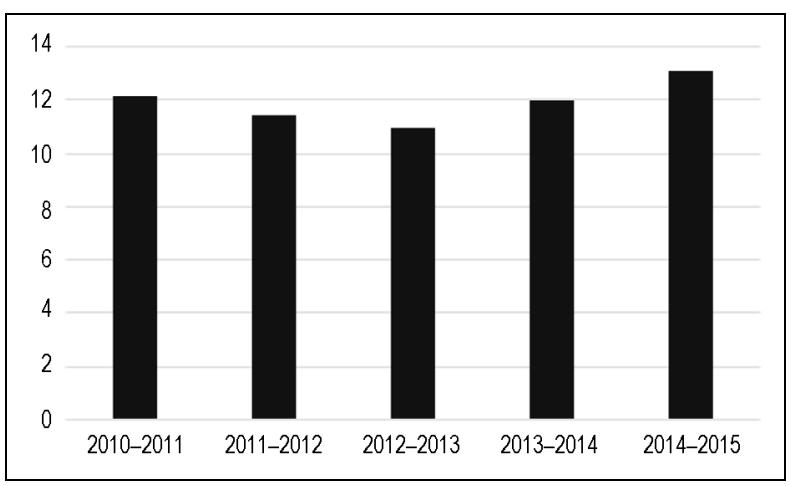

Fig. 1. Export income in Australia from education services trend 2010-2015, billion US dollars (Source: Australian Bureau of Statistics 2016) 
In Australia, the growth in international student numbers and in branch campus expansion has slowed and even begun to decline since the global financial crisis. But numbers have been rising again over the past five years. As of year-to-date June 2015, there were 464,787 international students studying in Australia on a student visa. This amounts to a $10.4 \%$ increase over the same period for 2014 .

This decline could be a result of higher market saturation because of the many new higher quality entrants from elsewhere, including exporters from Europe, North America, some Asian countries that are now targeting Asian students with offers with which Australian universities cannot easily compete. Plus, three additional factors have affected Australia uniquely and negatively: a doubling in the value of the Australian dollar over the past decade; tougher visa and post-study work restrictions; and bad media coverage - particularly in India on Australian treatment of its foreign students.

The top five nationalities for Australian offshore higher education provision were Singapore, Malaysia, China, Vietnam and Hong Kong. This is different to the top five nationalities (China, Malaysia, India, Hong Kong and Vietnam) represented in enrolments onshore in Australia.

Australia, like other majour TNE providing countries (USA, UK, Canada) not only have the entrepreneurial university expertise, but also are leading in the export of studies.

In order to keep attracting the students, it is not enough to count on the old models, traditional forms. All these countries are among those which are looking for the new forms: from traditional MOOCs to international branch campuses in foreign markets.

All these forms are the new models of international behavior, which are going to be continuously developed by the universities that are going down the entrepreneurial road.

\section{Turning tables}

Even though, universities from English speaking countries and countries with traditionally strong brand in education seem to have competitive advantage, HEIs from the emerging countries are increasingly successful at keeping up with the traditional leaders (Daquila 2013). An ongoing shift in higher education (changing role of government, increasing orientation of tradable service, business like behavior) enables the latecomers to find and exploit the most suitable models and markets (Gir- dzijauskaite, Radzeviciene 2013). Just like a change of rules in any game allows for the shift of leaders. Such conditions provide a playground for latecomer entrepreneurial universities.

The latter changes in higher education market, have led to the emergence of entrepreneurial university phenomena.

\section{Conclusions}

The hyper competition among HEIs has been growing globally. The demand and supply of educational services is imbalanced in many countries. HEIs from the countries were the supply exceeds the local demand are induced to attract foreign students. Markets with growing middle class and increased purchasing power are emerging with attractive conditions for educational service providers. However the local institutions are not always able to meet the growing customer needs in terms of quality and quantity. Thus, the market share is captured by international providers. This trend together with the decreasing public funding for higher education in many countries and transition from free to paid education conditions evolution of HEIs from local to international market players.

The latter changes bring HEIs closer to becoming entrepreneurial universities operating internationally: in order to fully exploit their potential universities seek in-come diversification, as well as the ways to enhance their international activities and make their educational services attractive in the foreign markets. In HE just as in business world, competitiveness is largely dependent on business internationalisation. With the globally increasing consuming of educational services, growing market, emerging educational and for profit competitors, increasingly proactive measures are taken to attract the customers.

Business models are increasingly used both in higher education theory and practices. After the theories analysis it is evident that concept equivalents from business are present in HE research such as educational service export, market share, market segmentation, full equity investment, etc. New kind of players in higher education market - business corporations providing educational services are seen as potential partners as well as rivals. Forprofit corporations are now targeting the higher education market.

A currently ongoing academic revolution consolidating an economic and social development mission is transforming the traditional teaching and research university into an entrepreneurial university. The Triple Helix thesis stipulates that the in- 
teraction among university-industry-government is the key to improving the conditions for innovation development in a knowledge-based society.

\section{References}

Barsony, J. 2003. Towards the entrepreneurial university, in SEFI Conference-Global Engineer: Education and Training for Mobility, 16-20 September 2013, Leuven, Belgium. European Society for Engineering Education.

Burnett, S. A. 2008. The impact of globalisation on higher education institutions in Ontario: Doctoral dissertation. University of Bath.

Clark, B. R. 1998. Creating entrepreneurial universities: organisational pathways of transformation. Guildford: Pergamon.

Clark, B. R. 2001. The entrepreneurial university: new foundations for collegiality, autonomy, and achievement, Higher Education Management 13(2): 9-24.

Clark, B. R 2015. The character of the entrepreneurial university, International Higher Education (38): $2-3$.

Ćulum, B.; Rončević, N.; Ledić, J. 2013. Facing new expectations - integrating third mission activities into the university, Vol. 5 in B. M. Kehm, U. Teichler (Eds.). The academic profession in Europe: New tasks and new challenges. Netherlands: Springer Netherlands, 163-195.

Currie, J. 2002. Australian universities as enterprise universities: transformed players on a global stage, in IAU International Conference, 18-21 April 2002, Quebec City, Canada.

Daquila, T. C. 2013. Internationalizing higher education in Singapore: Government policies and the NUS experience, Journal of Studies in International Education 17: 629-647.

http://dx.doi.org/10.1177/1028315313499232

Australian Bureu of Statistics. 2015. Education and work, Australia [online], [cited 15 January 2016]. Available from Internet:

http://www.abs.gov.au/ausstats/abs@.nsf/mf/6227.0

Etzkowitz, H.; Webster, A.; Gebhardt, C.; Terra, B. R. C. 2000. The future of the university and the university of the future: evolution of ivory tower to entrepreneurial paradigm, Research policy 29(2): 313 330. http://dx.doi.org/10.1016/S0048-7333(99)00069-4

Etzkowitz, H. 2004. The evolution of the entrepreneurial university, International Journal of Technology and Globalisation 1(1): 64-77. http://dx.doi.org/10.1504/IJTG.2004.004551

Etzkowitz, H. 2006. Triple Helix twins: innovation and sustainability, Science and Public Policy 33(1):7783. http://dx.doi.org/10.3152/147154306781779154
Fayolle, A.; Redford, D. T. 2014. Handbook on the entrepreneurial university. Edward Elgar Publishing.

Gallagher, S., Garrett, G. 2012. From university export to the multinational university. The internationalization of higher education in Australia and the United States [online] US Study Centre [cited 15 January 2016]. Available from Internet: http://ussc.edu.au/ussc/assets/media/docs/publicati ons/120801_MNUdraft_GallagherGarrett.pdf

Gibb, A.; Hannon, P. 2006. Towards the entrepreneurial university, International Journal of Entrepreneurship Education 4(1): 73-110.

Girdzijauskaite, E.; Radzeviciene, A. 2013. Opportunities of competitiveness of latecomer university, in $16^{\text {th }}$ Conference for Junior Researchers "ScienceFuture of Lithuania”, 7 February 2013, Vilnius, Lithuania.

Global Alliance for Transnational Education (GATE) 1997. Certification Manual.

Göransson, B.; Maharajh, R.; Schmoch, U. 2009. Introduction: New challenges for universities beyond education and research, Science and Public Policy 36(2): 83-84.

http://dx.doi.org/10.3152/030234209X406872

Guerrero-Cano, M. 2008. The creation and development of entrepreneurial universities in Spain. An institutional approach: Doctoral dissertation. Universitat Automona Barcelona Spain.

Gulbrandsen, M.; Slipersaeter, S. 2007. The third mission and the entrepreneurial university model, Chapter 4 in A. Bonaccorsi, C. Daraio (Eds.). Universities and strategic knowledge creation. United Kingdom: Edward Elgar, 112-143. http://dx.doi.org/10.4337/9781847206848.00011

Jacob, M.; Lundqvist, M.; Hellsmark, H. 2003. Entrepreneurial transformations in the Swedish university system: the case of Chalmers University of Technology, Research Policy 32(9): 1555-1568. http://dx.doi.org/10.1016/S0048-7333(03)00024-6

Kirby, D. A. 2006. Creating entrepreneurial universities in the UK: applying entrepreneurship theory to practice, The Journal of Technology Transfer 31(5): 599-603. http://dx.doi.org/10.1007/s10961-006-9061-4

Knight, J. 2002a. GATS and higher education - online discussion [online]. 4 April 2002 [cited 15 January 2016]. Available from Internet: http://goo.gl/OXD7ze

Knight, J. 2002b. Trade in higher education services: the implications of GATS. The Observatory on Borderless Higher Education, London.

Knight, J. 2002c. The impact of trade liberalization on higher education: policy implications. Paper presented at the "Globalisation: What issues are at stake for universities?" Conference, 18-21 April 2002, University of Laval, Quebec, Canada. 
Knight, J. 2003. GATS, trade and higher education: perspective 2003-where are we? [online] The Observatory on Borderless Higher Education, London [cited 15 January 2016]. Available from Internet: http://200.229.43.1/imagedb/documento/DOC_DS C_NOME_ARQUI20060214115610.pdf

Knight, J. 2006. Higher education crossing borders: a guide to the implications of the general agreement on trade in services (GATS) for cross-border education. Commonwealth of Learning, UNESCO.

Lazzeroni, M.; Piccaluga, A. 2003. Towards the entrepreneurial university, Local Economy 18(1): 38-48. http://dx.doi.org/10.1080/0269094032000073807

Leydesdorff, L. 2012. The triple helix, quadruple helix,..., and an n-tuple of helices: explanatory models for analyzing the knowledge-based economy?, Journal of the Knowledge Economy 3(1): 25-35. http://dx.doi.org/10.1007/s13132-011-0049-4

Mohrman, K.; Ma, W.; Baker, D. 2008. The research university in transition: the emerging global model, Higher Education Policy 21(1): 5-27. http://dx.doi.org/10.1057/palgrave.hep.8300175

Naidoo, V. 2008. From Ivory Towers to international business: are universities export ready in their recruitment of international students?, Journal of Studies in International Education 14(1): 5-28. http://dx.doi.org/10.1177/1028315308327953

OECD. 2012. Education at a glance [online]. OECD publishing [cited 15 January 2016]. Available from Internet: https://www.oecd.org/edu/EAG\%202012 e-book EN 200912.pdf

Pinheiro, R.; Stensaker, B. 2014. Designing the entrepreneurial university: The interpretation of a global idea, Public Organization Review 14(4): 497 516. http://dx.doi.org/10.1007/s11115-013-0241-z
Radzeviciene, A.; Girdzijauskaite, E. 2012. Multilateral partnership management in higher education: the network approach, in International Conference Contemporary Issues in Business, Management and Education, 15 November 2012,Vilnius, Lithuania.

Sam, C.; van der Sijde, P. 2014. Understanding the concept of the entrepreneurial university from the perspective of higher education models, Higher Education 68(6): 891-908. http://dx.doi.org/10.1007/s10734-014-9750-0

Tilak, J. B. 2008. Higher education: a public good or a commodity for trade?, Prospects 38(4): 449-466. http://dx.doi.org/10.1007/s1 1125-009-9093-2

Trencher, G.; Yarime, M.; McCormick, K. B.; Doll, C. N.; Kraines, S. B. 2014. Beyond the third mission: Exploring the emerging university function of co-creation for sustainability, Science and Public Policy 41(2): 151-179. http://dx.doi.org/10.1093/scipol/sct044

Wasser, H. 1990. Changes in the European university: From traditional to entrepreneurial, Higher Education Quarterly 44(2): 110-122.

http://dx.doi.org/10.1111/j.1468-2273.1990.tb01530.x

Wilkins, S.; Huisman, J. 2013. Student evaluation of university image attractiveness and its impact on student attachment to international branch campuses, Journal of Studies in International Education 17(5): 607-623. http://dx.doi.org/10.1177/1028315312472984

Wong, P. K.; Ho, Y. P.; Singh, A. 2007. Towards an "entrepreneurial university" model to support knowledge-based economic development: the case of the National University of Singapore, World Development 35(6): 941-958. http://dx.doi.org/10.1016/j.worlddev.2006.05.007 